\title{
Site and hybrid-specific agrotechnical models in sweet corn production
}

\author{
Ádám Lente \\ Centre For Agricultural and Applied Economic Sciences \\ Faculty of Agricultural and Food Sciences and Environmental Management \\ Institute of Crop Sciences \\ Debrecen, Böszörményi Str. 138 \\ lente@agr.unideb.hu
}

Keywords: sweet corn, sowing time, fertilization, hybrid, plant density, crop yield

SUMARRY

\begin{abstract}
The effect of three agrotechnical factors (sowing time, fertilization, plant density) and two genotypes on the crop yield of sweet corn was examined on chernozem soil in the Hajdúság region in two different crop years. Compared to the 30-year average, the climate was dry and warm in 2009 and humid in 2010. The experiments were conducted at the Látókép Research Site of the University of Debrecen. In the experiments we applied two sowing times (end of April, end of May), six fertilization levels (control, $N_{30}+P K, N_{60}+P K, N_{90}+P K, N_{120}+P K$, $N_{150}+P K$ ) and two crop density levels (45 thousand $\mathrm{ha}^{-1}$, 65 thousand ha ${ }^{-1}$ ). The hybrids we used were Jumbo and Enterprise. As regards the requirements of sweet corn production, the crop year of 2009 was dry and warm. The effect of moisture deficiency was more adverse on the crop yields with the second sowing time. On the contrary, the other examined year (2010) was significantly humid; the precipitation was 184 mm above the 30-year average and the temperature was average.

In the dry and hot crop year, the best yields were obtained with the hybrid Jumbo $\left(25677 \mathrm{~kg}^{-1}\right)$ at 65 thousand ha-1 plant density level on the average of the fertilization levels. The crop yields of Enterprise were also the highest at high plant density level (24444 $\mathrm{kg}$ ha $\left.{ }^{-1}\right)$. With the second sowing time the highest yields were obtained at the higher plant density level (65 thousand ha-1) with both hybrids (Jumbo $18978 \mathrm{~kg}$ ha-

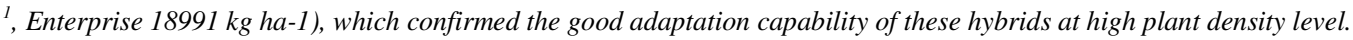

In humid crop year with early sowing time the highest yielding hybrid was Enterprise (at 45 thousand ha $\mathrm{crop}^{-1}$ density level $20757 \mathrm{~kg}^{-1}$ ), at the same time, Jumbo was best yielding at the higher plant density level (18781 $\left.\mathrm{kg}^{-1}\right)$. With the second sowing time the highest crop yield was obtained with Enterprise again (20628 $\mathrm{kg} \mathrm{ha}^{-1}$ at 65 thousand ha-1 plant density level). With this sowing time the average yields of Jumbo, was $18914 \mathrm{~kg} \mathrm{ha}^{-1}$ respectively. We found that dry crop year and early sowing time provided the best conditions for sweet corn production; the highest yields were obtained under these circumstances, which might be the results of the outstanding water management of chernozem soils.
\end{abstract}

\section{REVIEW OF SCIENTIFIC LITERATURE}

Sweet corn is a subspecies of maize; it differs from maize in that it has a recessive gene (sugary endosperm) on the 4th chromosome. The total production area of sweet corn is around 500 thousand ha globally. The leading countries in sweet corn production are the USA and Canada, but Hungary is also important, with over 100 thousand tons of export (Zsombik-Daróczi, 2008).

According to Tracy (2001), sweet corn is a field vegetable suitable for both fresh use and for processing. The growing demand for sweet corn triggered the increase of the production area in Europe, Asia and South America, and the processed amount has increased by $60 \%$ during the last 25 years in the United States (Williams et al., 2006). The major physiological processes of sweet corn are determined by temperature; however, as yield potential is high, harmonized and abundant water supply is equally important. According to Hodossi (2004), the monthly water demand of sweet corn is over $100 \mathrm{~mm}$. Of field vegetables, sweet corn has the longest sowing period, which is over three months, lasting from mid April (early) to early July (late) (Williams, 2008). According to Pereczes (1999), sweet corn requires warm temperatures and germination starts only if soil temperature is higher than $10{ }^{\circ} \mathrm{C}$. Based on its temperature requirement, it is suitable to be produced in the whole country.

According to the calculations of Debreceniné, the dry matter production of sweet corn can reach 245 $\mathrm{kg} / \mathrm{ha} /$ day. This rate decreases to 204, 200 and $82 \mathrm{~kg} / \mathrm{ha} /$ day in case of phosphorus, potassium and nitrogen deficiency, respectively. According to the new environmentally conscious agricultural advisory systems the specific nutrient content of sweet corn at $11 \mathrm{t} / \mathrm{ha} \mathrm{CCM}$ yield is $\mathrm{N} 10 \mathrm{~kg}$; P2O5 $4 \mathrm{~kg}$; K2O $11 \mathrm{~kg}$ (based on Terbe et al., 2004).

Géczi (2003) claims that the nutrient requirement of sweet corn is $120 \mathrm{~kg} / \mathrm{ha}$ of nitrogen, $80-100 \mathrm{~kg} / \mathrm{ha}$ of phosphorus and $100 \mathrm{~kg} / \mathrm{ha}$ of potassium active agent, which can be increased if irrigation is applied.

According to Nigicser (1997), depending on the nutritional supply of the soil $60-80 \mathrm{~kg}$ of phosphorus and $80-100 \mathrm{~kg}$ of potassium should be applied as base fertilizer before ploughing. In his cultivation and plant spacing experiment, Akmar (2002) applied $80 \mathrm{~kg}$ of phosphorus in autumn and $150 \mathrm{~kg}$ of nitrogen in autumn and in spring in the 8-10 leaves stage. Sárvári showed that the difference between the nutrient utilization capacity of sweet corn hybrids may exceed 50\%. According to Hodissi et al., (2004) the crop density ranges between 40 thousand and 70 thousand plants/ha according to the moisture conditions. Based on his experiments in 2005 and 2006, Kumar (2009) found that the optimal plant density for sweet corn is 83 thousand plants/ha and the optimal fertilization level is $120 \mathrm{~kg} / \mathrm{ha} \mathrm{N}$. 


\section{MATERIAL AND METHODS}

The experiment was carried out at the Látókép Plant Cultivation Research Site of the Debrecen University. The site is about $15 \mathrm{~km}$ from Debrecen, near Route 33 on the loess ridge of the Hajdúság region. Based on its physical characteristics, the soil belongs to the semi-compacted clay category.

The pre-crop of the examined stands was winter wheat, which is an excellent pre-crop for sweet corn.

In the crop years two commercially produced hybrids of the mid-late maturity group were used, namely Jumbo and Enterprise. The first sowing time (early) was at the beginning of the main sowing period (April 21, 2009 and April 27, 2010), the second (late) was a month later at the end of the main sowing period (May 19, 2009 and 26 May, 2010).

Six fertilization levels and two crop density levels were analyzed in the experiment.

The following fertilizer levels were applied: control (untreated), $\mathrm{N}=30 \mathrm{~kg} \mathrm{ha}^{-1}, \mathrm{P}_{2} \mathrm{O}_{5}=22.5 \mathrm{~kg} \mathrm{ha}^{-1}$, $\mathrm{K}_{2} \mathrm{O}=26.5 \mathrm{~kg} \mathrm{ha}^{-1}$ as base fertilizer and 2, 3, 4 and 5 times these quantities.

In both years two plant density levels were used (45 thousand ha ${ }^{-1}, 65$ thousand ha ${ }^{-1}$ ).

The arrangement of the plots is random block in four repetitions; the plot size was $11.4 \mathrm{~m}^{2}$. Sweet corn with the husk on was harvested by hand. The moisture content of the kernels ranged between 67 and $69 \%$, which is optimal for the canning industry.

Table 1 shows the monthly precipitation and temperature values in the examined crop years.

The crop year of 2009 was dry and hot as regards sweet corn production. With the early sowing time, the total amount of precipitation in the vegetation period was $110.6 \mathrm{~mm}$ below and the average temperature was $2.5{ }^{\circ} \mathrm{C}$ above the 30-year average (April, May, June, July). With the late sowing time the moisture deficiency was even higher $(160 \mathrm{~mm})$ while the temperature was $2.6^{\circ} \mathrm{C}$ above the average (April, May, June, July, August). On the contrary, the crop year of 2010 was outstandingly wet. With the early sowing time, the total amount of precipitation in the vegetation period was $339 \mathrm{~mm}$, which was $93 \mathrm{~mm}$ above the 30 -year average; the average temperature was $1.5^{\circ} \mathrm{C}$ above the 30-year average (April, May, June, July). With the late sowing time the surplus precipitation was $24.7 \mathrm{~mm}$ and the temperature was $0.7^{\circ} \mathrm{C}$ over the 30 -year average.

Table 1

Meteorological data of the crop year (Debrecen)

\begin{tabular}{|c|c|c|c|c|c|c|}
\hline \multirow{2}{*}{ Month } & \multicolumn{3}{|c|}{ Monthly precipitation $(\mathbf{m m})$} & \multicolumn{3}{c|}{ Monthly average temperature $\left({ }^{\circ} \mathbf{C}\right)$} \\
\cline { 2 - 7 } & Year 2009 & Year 2010 & 30 year average & Year 2009 & Year 2010 & 30 year average \\
\hline April & 9,9 & 83,3 & 42,4 & 14,9 & 11,6 & 10,7 \\
\hline May & 20,1 & 111,4 & 58,8 & 17,4 & 16,6 & 15,8 \\
\hline June & 96,6 & 100,9 & 79,5 & 19,8 & 19,7 & 18,7 \\
\hline July & 9,2 & 97,2 & 65,7 & 23,4 & 22 & 20,3 \\
\hline August & 11,3 & 98,3 & 60,7 & 22,6 & 19 & 19,6 \\
\hline Total/average & $\mathbf{1 4 7 , 1}$ & $\mathbf{4 9 1 , 1}$ & $\mathbf{3 0 7 , 1}$ & $\mathbf{1 9 , 6}$ & $\mathbf{1 7 , 8}$ & $\mathbf{1 7}$ \\
\hline
\end{tabular}

\section{EVALUATION OF THE RESULTS}

The yield potential of hybrids is different and genetically determined. Yield potential is equally influenced by the crop year and the applied agrotechniques.

In the dry and hot crop year of 2009 the total precipitation was $160 \mathrm{~mm}$ below the 30 -year average. The highest moisture deficiency was detected in July, when only $14 \%(9.2 \mathrm{~mm})$ of the average amount $(65.7 \mathrm{~mm})$ was obtained. June was the only month when the precipitation was (by $17.1 \mathrm{~mm}$ ) above the 30-year average $(96.6 \mathrm{~mm})$. With the early sowing time, the moisture deficiency in April and May was well compensated by the moisture gathered in autumn and winter; the precipitation in June ensured sufficient moisture until the end of the vegetation period. On the contrary, due to minimal precipitation values in July (9.2) and August (11.3 mm), there was significant yield loss with the second sowing time.

In the 2010 crop year, the precipitation increased the 30-year average by $184 \mathrm{~mm}$ in the vegetation period (from April to August). In the first month, the precipitation was double and the temperature was higher by almost $1{ }^{\circ} \mathrm{C}$ than the 30-year average with the first sowing time (April). Similarly, in May (second sowing time) the precipitation was almost double and the temperature was $0.8^{\circ} \mathrm{C}$ above the 30 -year average. The high amount of precipitation and the extreme temperature values caused yellowing of the plant leaves. In the flowering stage in the first sowing time (beginning of July), the temperature increased the 30-year average by $1.7 \%$, while the precipitation was almost 1.5 times higher. August was the only month when the monthly mean temperature was below the average, but even in this month the precipitation was $31.5 \mathrm{~mm}$ higher than the average. Due to the high amount of precipitation, the vertical movement of soil nutrients increased and unfavorably influenced the nutrient uptake of plants. Additionally, the soil compacting effect of the intensive rainfall caused significant depression in the plant stands and led to anaerobic soil conditions. 
The effect of agrotechnical factors on the yield of sweet corn in dry crop year $\left(\mathrm{kg} \mathrm{ha}^{-1}\right)$

(Debrecen, 2009)

\begin{tabular}{|c|c|c|c|c|c|c|c|c|c|c|}
\hline Sowing time & Plant density & Hybrid $(A) / F \operatorname{Fert}(B)$ & $\varnothing$ & $N 30+P K$ & $N 60+P K$ & $N 90+P K$ & $N 120+P K$ & $N 150+P K$ & \multicolumn{2}{|c|}{$L S D_{5 \%}$} \\
\hline \multirow{4}{*}{ I. } & \multirow{2}{*}{45 thousand $\mathrm{ha}^{-1}$} & Jumbo & 22401 & 22270 & 24967 & 25674 & 27007 & 24243 & $3322(\mathrm{~A})$ & \multirow{2}{*}{2964 (AXB) } \\
\hline & & Enterprise & 22336 & 24605 & 25592 & 25312 & 25132 & 22220 & 2029 (B) & \\
\hline & \multirow{2}{*}{65 thousand $\mathrm{ha}^{-1}$} & Jumbo & 24589 & 25806 & 26464 & 25757 & 27253 & 24194 & $2143(\mathrm{~A})$ & \multirow{2}{*}{2491 (AXB) } \\
\hline & & Enterprise & 22385 & 24260 & 24095 & 25526 & 26382 & 24013 & $1762(\mathrm{~B})$ & \\
\hline \multirow{4}{*}{ II. } & \multirow{2}{*}{45 thousand $\mathrm{ha}^{-1}$} & Jumbo & 17187 & 17747 & 17286 & 19145 & 14507 & 17944 & 4130 (A) & \multirow{2}{*}{3054 (AXB) } \\
\hline & & Enterprise & 22270 & 17862 & 19161 & 17368 & 15757 & 17681 & 2160 (B) & \\
\hline & \multirow{2}{*}{65 thousand ha ${ }^{-1}$} & Jumbo & 20921 & 17812 & 19572 & 19293 & 19194 & 17072 & 2925 (A) & \multirow{2}{*}{3401 (AXB) } \\
\hline & & Enterprise & 21513 & 20444 & 18569 & 19441 & 19128 & 14852 & 2405 (B) & \\
\hline
\end{tabular}

Some agrotechnical factors (sowing time, crop density and fertilization) and two different sweet corn genotypes were investigated in small plot field experiments under excellent conditions at the Látókép Research Site of the University of Debrecen, Faculty of Agriculture.

Sweet corn has a high requirement for nutrients and well utilizes both the natural nutrient supply of the soil and the artificial fertilizers as well. The efficiency of fertilization is significantly influenced by soil conditions, water supply, genotypes and agrotechnical factors.

The optimal fertilization level of the specific hybrids was examined at different fertilization doses. Table 2 and Table 3 shows the crop yields of the hybrids, the bold numbers indicate the agroecologic maximum crop yield of the hybrid. Agroecologic fertilization optimum is the level over which the increase of the crop yield is not significant. In the crop year of 2009, the crop yields of Jumbo and Enterprise obtained with the agroecologic fertilization optimum were similar with the early sowing time at both plant density levels (Table 2). The agroecologic optimum of Jumbo was at $\mathrm{N}_{90}+\mathrm{PK}\left(25674 \mathrm{~kg} \mathrm{ha}^{-1}\right)$ at the lower crop density level and at $\mathrm{N}_{120}+\mathrm{PK}$ $\left(27253 \mathrm{~kg} \mathrm{ha}^{-1}\right)$ at the higher plant density level. The agroecologic optimum of Enterprise was at $\mathrm{N}_{60}+\mathrm{PK}(25592$ $\mathrm{kg} \mathrm{ha}^{-1}$ ) and $\mathrm{N}_{120}+\mathrm{PK}\left(26382 \mathrm{~kg} \mathrm{ha}^{-1}\right)$. With the second (late) sowing time, the crop yield of Enterprise was higher (45 thousand ha ${ }^{-1}: 22270 \mathrm{~kg} \mathrm{ha}^{-1}, 65$ thousand $\mathrm{ha}^{-1}: 21513 \mathrm{~kg} \mathrm{ha}^{-1}$ ) at both plant density levels. The agroecologic optimum was the control fertilization level in both cases and for both hybrids. Increasing fertilization induced yield depression as a result of water deficiency in the crop stand. Similarly, the average crop yield of Enterprise was highest $\left(24444 \mathrm{~kg} \mathrm{ha}^{-1}\right)$ in this treatment.

The effect of agrotechnical factors on the yield of sweet corn in humid crop year $\left(\mathrm{kg} \mathrm{ha}^{-1}\right)$

(Debrecen, 2010)

\begin{tabular}{|c|c|c|c|c|c|c|c|c|c|c|}
\hline Sowing time & Plant density & $\operatorname{Hybrid}(A) / F \operatorname{Fert}(B)$ & $\varnothing$ & $N_{30}+P K$ & $N_{60}+P K$ & $N_{90}+P K$ & $N_{120}+P K$ & $N_{150}+P K$ & \multicolumn{2}{|c|}{$L S D_{5 \%}$} \\
\hline \multirow{4}{*}{ I. } & \multirow{2}{*}{45 thousand $h^{-1}$} & Jumbo & 12582 & 15395 & 15937 & 16809 & 17007 & 18487 & 3991(A) & \multirow{2}{*}{ 1970(AxB) } \\
\hline & & Enterprise & 16612 & 19457 & 20428 & 22500 & 22105 & 23437 & 985(B) & \\
\hline & \multirow{2}{*}{65 thousand $h a^{-1}$} & Jumbo & 14296 & 15543 & 19030 & 20099 & 22253 & 21464 & $2000(\mathrm{~A})$ & \multirow{2}{*}{ 2048(AxB) } \\
\hline & & Enterprise & 16546 & 18536 & 20641 & 20444 & 23061 & 22204 & 1024(B) & \\
\hline \multirow{4}{*}{ II. } & \multirow{2}{*}{45 thousand $\mathrm{ha}^{-1}$} & Jumbo & 13470 & 15724 & 17056 & 17730 & 18454 & 16414 & $2727(\mathrm{~A})$ & \multirow{2}{*}{$2267(\mathrm{AxB})$} \\
\hline & & Enterprise & 16266 & 17714 & 17993 & 18536 & 18273 & 18635 & 1134(B) & \\
\hline & \multirow{2}{*}{65 thousand $\mathrm{ha}^{-1}$} & Jumbo & 18289 & 18882 & 18980 & 17845 & 20888 & 18602 & 2132(A) & \multirow{2}{*}{$2428(\mathrm{AxB})$} \\
\hline & & Enterprise & 18306 & 19687 & 21546 & 20444 & 21546 & 22237 & 1214(B) & \\
\hline
\end{tabular}

In the humid 2010 crop year, the crop yields (Table 3) at the agroecologic optimal fertilization levels $\left(\mathrm{N}_{150}+\mathrm{PK}\right)$ was highest with Enterprise in both sowing times $\left(1^{\text {st }}\right.$ sowing time: $23061 \mathrm{~kg} \mathrm{ha}^{-1}, 2^{\text {nd }}$ sowing time: $22237 \mathrm{~kg} \mathrm{ha}^{-1}$ ). In the second sowing time, there was significant difference between the average yields of Jumbo and Enterprise at the higher plant density level with the agroecologic fertilization optimum.

We examined the effect of fertilizer treatments on the increase of crop yields. The basis of the relation is the control treatment that represents the natural nutrient supply of the soil; the nutrient supply was utilized at different extent in the different crop years. This proportion well represents the effect of the specific fertilizer levels on the 
increase or decrease of crop yield, which can be considered as abiotic stress (Bocz, 1976). In dry crop year the yield of control plots were relatively high $\left(22336-24589 \mathrm{~kg} \mathrm{ha}^{-1}\right)$, which proves the sufficient uptake and utilization of soil nutrients. In this case the increasing fertilizer levels (10.8-17.9\% surplus yield) caused no significant increase in crop yield. With the late sowing time, crop yields decreased at all fertilization levels. On the contrary, in humid year the crop yield of the control plots was well below that of the yields obtained at the agroecologic fertilization optimum. The reason might be that the intensive precipitation washed off the nutrients from the root zone. Crop yield increase was significantly higher in 2010 compared to the dry year. It ranged between 35.4 and $53.3 \%$ with the early sowing time and between 14,2-37,0\% with the late sowing time.

\section{CONCLUSIONS}

The effects of the genotype and agrotechnical factors on the crop yield of sweet corn were analyzed in two sowing times in two different crop years. The crop year of 2009 was rather warm and dry; the precipitation was less than half of the 30-year average. On the contrary, the crop year of 2010 was extremely humid and the amount of rainfall was significantly above the 30 -year average, through washing off the nutrients and deteriorating soil structure it had an unfavorable effect on the crop yield of 2010.

We found that the early sowing time in the crop year of 2009 was most favorable for sweet corn production; the moisture content of the soil was sufficient for the plants. The crop yield of both hybrids was above $24 \mathrm{t} \mathrm{ha}{ }^{-1}$. In the lower crop density treatment the agroecologic fertilization optimum was lower $\left(\mathrm{N}_{60}+\mathrm{PK}\right.$ for Enterprise, $\mathrm{N}_{90}+\mathrm{PK}$ for Jumbo), while with the higher crop densities the higher fertilization level proved to be better $\left(\mathrm{N}_{120}+\mathrm{PK}\right)$. The late sowing time enhanced the unfavorable effects of dry and hot weather. On the average of the fertilizer levels, the crop yields of both Jumbo and Enterprise exceeded $19 \mathrm{ha}^{-1}$, while the highest crop yields were obtained with both hybrids on the control plots (agroecological fertilization optimum). In both treatments the higher plant density levels proved to be better.

In the crop year of 2010, no significant differences were found between the average yields of the two hybrids with the two sowing times. However, as regards the maximum crop yields, the first sowing time proved to be better $\left(18487 \mathrm{~kg} \mathrm{ha}^{-1}-23437 \mathrm{~kg} \mathrm{ha}^{-1}\right)$. At the same time, the difference between crop density levels was mitigated by the sufficient water supply with the first and more favorable sowing time, since with the low plant density level plants could compensate for the smaller number of plants by producing a second corncob. We also found that the interval of the agroecologic fertilization optimum was wider $\left(\mathrm{N}_{60-120}+\mathrm{PK}\right)$ with the late sowing time than with the first sowing time $\left(\mathrm{N}_{120-150}+\mathrm{PK}\right)$, irrespective of treatments and hybrids.

Summarizing, based on crop yields obtained with the agroecologic fertilization levels both Jumbo and Enterprise gave excellent yields in dry crop year, while in humid crop year the yield of Enterprise was higher.

\section{REFERENCES}

Akmar Z. (2002): Effect of tiller removing and plant density on ear yield of sweet corn (Zea mays saccharata Sturt). Pakistan Journal of Biological Sciences. 5: 9. 906-908.

Balázs S. (1994): Zöldségtermesztők kézikönyve. Mezőgazda Kiadó, Budapest. 631-639.

Bocz E. (1976): Trágyázási útmutató. Mezőgazdasági kiadó, Budapest. 117-146.

Debreczeni B.-né (2005): Korszakváltás a tápanyag-gazdálkodásban. In: Pepó P. (Szerk.) Korszakváltás a hazai mezőgazdaságban: a modern növénytermesztés alapjai. Debreceni Egyetem Agrártudományi Centrum. 66-70 p.

Gécz L. (2003): Piacos Zöldségtermesztés. Szaktudás Kiadó Ház, Budapest. 128-133.

Hodossi S.-Kovács A.-Terbe I. (2004): Zöldségtermesztés szántóföldön. Mezőgazda Kiadó, Budapest. 340-348.

Kumar A.: 2009. Production potential and nitrogen-use efficiency of sweet corn (Zea mays ) as influenced by different planting densities and nitrogen levels. Indian Journal of agricultural siences. 79: 7. 351-355.

Nigicser T. (1997): Csemegekukorica. Magyar Mezőgazdaság, 52: 38. 30-31.

Pereczes J. (1999): Csemegekukorica. In: Mártonffy B., Rimóczi I. (Szerk.) Nagymagvú zöldségfélék. Budapest., Mezőgazda Kiadó, 50-72.

p.

Sárvári M. (2000): Fajtaspecifikus kukoricatermesztési technológiák fejlesztése. Agrofórum. 11:3. 53-55.p.

Terbe I.-Slezák K.-Kappelen N. (2004): A talajművelés és tápanyag-utánpótlás helyzete a szántóföldi zöldségtermesztő gazdaságokban.

Gyakorlati Agrofórum, 12 (1) 2-6.p.

Tracy, W.F. (2001): Sweet corn. FL: CRC Press. 155-197.

Williams, Martin M. (2008): Sweet corn growth and yield responses to planting dates of the north central United States. Hortscience, 43 : 6. 1775-1779.

Williams, Martin M.-Masiunas, B. J. (2006): Functional relationships between giant ragweed (Amrosia trifida) interference and sweet corn yield and ear traits. Weed Science, 54: 54. 948-953.

Zsombik L.-Daróczi M. (2008): A csemegekukorica termesztésének helyzete és aktualitásai. Agrárágazat. 9: $2.24-26$. 